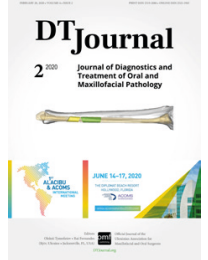

Editorial

\title{
Introducing a New Editorial Board Member from Italy: Olindo Massarelli, MD, PhD, FEBOMFS
}

\author{
Oleksii 0. Tymofieievª, levgen I. Fesenko ${ }^{\mathrm{b}, *}$, \& Evangelos G. Kilipiris
}

A leader is one who knows the way, goes the way, and shows the way.

-John C. Maxwell

American author, speaker, and pastor

What a happy and honored month in a life of the Journal of Diagnostics and Treatment of Oral and Maxillofacial Pathology! What's a reason? In February 2020 a true leader, Olindo Massarelli (Fig 1), MD, PhD, FEBOMFS, joined the Editorial Board's family. His famous name, surgical skills, and a kind scientific support has started permanently to make us stronger, wiser, and even more specialized in the field of head neck reconstructive surgery. His recent publication focused on IGTV chimeric flap case and reconstruction of Cordeiro type IIIA total maxillectomy defect ${ }^{1}$ inspired us for new goals and gave us a new vision of things. One of which is to expand the journal's share of articles in the direction of microvascular operations.

Dr. Oleksii O. Tymofieiev: After Dr. Massarelli`s kind support of our humble ideas, the number of

\footnotetext{
a Editor in Chief, DTJournal.org; Kyiv, Ukraine

E-mail: tymofeev@gmail.com (Oleksii Tymofieiev)

${ }^{\mathrm{b}}$ Managing Editor, DTJournal.org; Kyiv, Ukraine

E-mail: i.i.fesenko@dtjournal.org (levgen Fesenko)

Instagram: dr_eugenfesenko

Director, Journal Development Department

DTJournal.org; Thessaloniki, Greece | Bratislava, Slovak Republic

E-mail: varonos@live.co.uk (Evangelos Kilipiris)

Instagram: evangeloskilipiris

*Corresponding author's address: Department of Oral and Maxillofacial Surgery, Private Higher Educational Establishment "Kyiv Medical University."
}

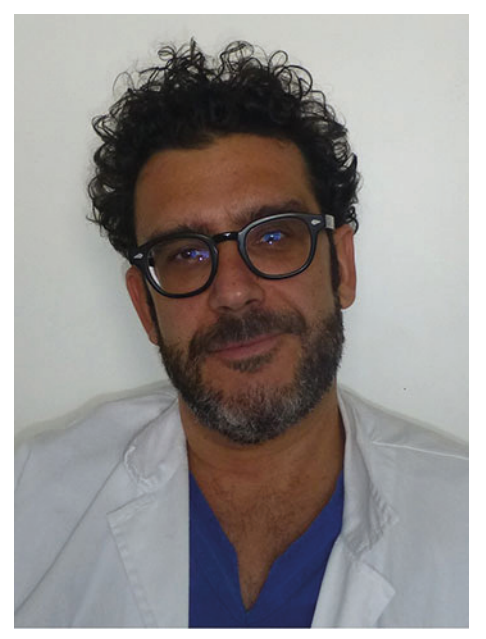

FIGURE 1. Dr. Olindo Massarelli.

EB members, who deeply involved into moving the jaw reconstructive surgery's science, increased to 5 opinion leaders: Drs. Rui P. Fernandes (USA), Oleh M. Antonyshyn (Canada), Todd C. Hanna (USA), Anthony M. Bunnell (USA), and Olindo Massarelli (Italy).

\section{Antona Tsedika Street, Kyiv 02000, Ukraine.} Tel.: +380632931813

Cite article as: Tymofieiev OO, Fesenko II, Kilipiris EG. Introducing a new editorial board member from Italy: Olindo Massarelli, MD, PhD, FEBOMFS. J Diagn Treat Oral Maxillofac Pathol 2020;4(2):23-24.

Paper received 21 February 2020

Accepted 26 February 2020

Available online 28 February 2020

https://dx doi.org/10.23999/j.dtomp.2020.2.2.

(c) 2020 OMF Publishing, LLC. This is an open access article under the CC BY license (http://creativecommons.org/licenses/by-nc/4.0/). 
Dr. Ievgen I. Fesenko: Thanks to Dr. Hanna, our journal's connection and collaboration with Dr. Massarelli became possible and made a huge contribution to the journal's evolution. Every last decade's masterpiece by Dr. Massarelli (Fig 2) and his Italian colleagues ${ }^{2-8}$ is more than impressive and makes a tremendous impact on different specialties, especially oral and maxillofacial, head neck surgeries. For me personally, a study dedicated to a chimeric lateral supramalleolar artery perforator fibula free flap ${ }^{9}$ became a most readied/analyzed article in my Apple Books application (Apple Inc., Cupertino, CA, USA).

Dr. Evangelos G. Kilipiris: As our journal continues to grow steadily, is a privilege for our expanding team and for me personally to announce a new Editorial Board Member, Dr. Massarelli, a pioneer in microvascular surgery. A warm welcome.

I think we will grow together and also we will raise important results.

-Dr. Olindo Massarelli (personal communication, February 13, 2020)

Editorial Board Member, DTJournal.org

The future of microvascular surgery is bright and clear..$^{10}$ -Dr. Vijay Kumar King George Medical University, India

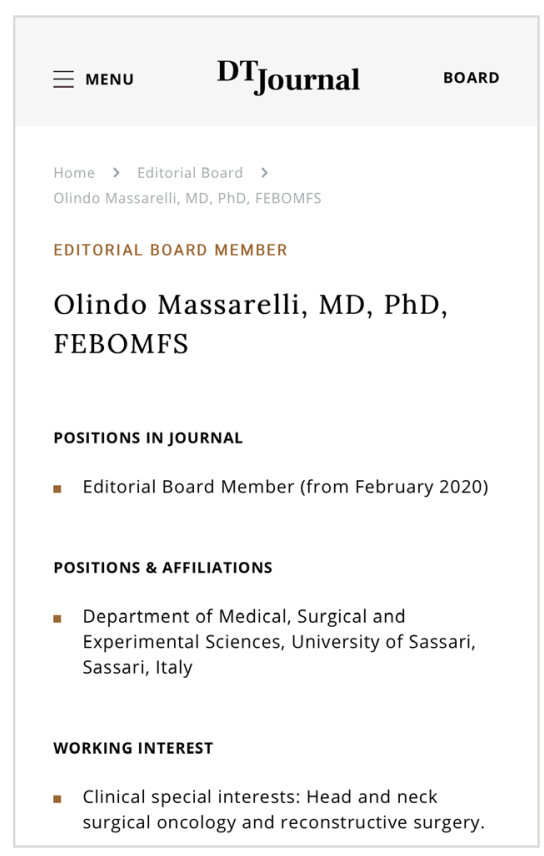

FIGURE 2. Cropped smartphone screenshot of the Dr. Massarelli's page at dtjournal. org gives an opportunity to get acquainted with his interests, books, and recent articles.

\section{REFERENCES}

1. Massarelli O, Hanna TC, Ganry L, Nagorniak IV, Fesenko II. Impact of surgeon's Instagram television (IGTV): a case of chimeric fibula and soleus muscle transplant in a reconstruction of Cordeiro type IIIA total maxillectomy defect. J Diagn Treat Oral Maxillofac Pathol 2020;4(1):3-20. https://dx.doi.org/10.23999/j. dtomp.2020.1.2.

2. Baserga C, Massarelli O, Bolzoni AR, Rossi DS, Beltramini GA, Baj A, Giannì AB. Fibula free flap pedicle ossification: Experience of two centres and a review of the literature. J Craniomaxillofac Surg 2018;46(9):16748. https://dx.doi.org/10.1016/j.jcms.2018.06.019.

3. Massarelli O, Vaira LA, GobbiR, Biglio A, Dell'aversana Orabona G, De Riu G. Soft palate functional reconstruction with buccinator myomucosal island flaps. Int J Oral Maxillofac Surg 2018;47(3):316-23. https://dx.doi.org/10.1016/j.ijom.2017.11.012.

4. Massarelli O. Chapter 10b2: Perforators myomucosal cheek flaps. In: Microsurgery Manual of the Italian Society of Microsurgery (SIM) on "Perforator, propeller and freestyle pedicled flaps." Moschella F, Toia F, Cordova A, D'Arpa S, editors [Italian]. Palermo: Palermo University Press; 2017:124-37.

5. Massarelli O, Gobbi R, Biglio A, Tullio A. Facial artery myomucosal free flap for cheek mucosa reconstruction: a case report. Microsurgery 2013;33(5):401-5. https:// dx.doi.org/10.1002/micr.22113.

6. Baj A, Beltramini GA, Massarelli O, Youssef DA, Giannì $\mathrm{AB}$. Minimally invasive harvest of free fibula flap. Plast Reconstr Surg 2013;131(3):474e-7e. https:// dx.doi.org/10.1097/PRS.0b013e31827c73f6.

7. Massarelli O, Baj A, Gobbi R, Soma D, Marelli S, De Riu G, Tullio A, Giannì AB. Cheek mucosa: a versatile donor site of myomucosal flaps. Technical and functional considerations. Head Neck 2013;35(1):10917. https://dx.doi.org/10.1002/hed.22933.

8. Beltramini GA, Massarelli O, Demarchi M, Copelli C, Cassoni A, Valentini V, Tullio A, Giannì AB, Sesenna E, Baj A. Is neck dissection needed in squamous-cell carcinoma of the maxillary gingiva, alveolus, and hard palate? A multicentre Italian study of 65 cases and literature review. Oral Oncol 2012;48(2):97-101. https://dx.doi.org/

9. Massarelli O, Gobbi R, Biglio A, Soma D, Tullio A. Chimeric lateral supramalleolar artery perforator fibula free flap in the reconstruction of composite head and neck defects. Plast Reconstr Surg 2014;133:130-6. https://dx.doi.org/10.1097/01.prs.0000435845.33670.64.

10. Kumar V. Micro surgery - need of the hour. Natl J Maxillofac Surg 2016;7(2):113-4. https://dx.doi. org/10.4103/njms.NJMS_8_17. 